\title{
B-type natriuretic peptide is a useful biomarker predicting disease severity in children with isolated bronchiolitis in the emergency department
}

\author{
Murat Anı1 ${ }^{1}$, Zeynep Göç ${ }^{1}$, Ramazan $\mathrm{Avc1}^{3}$, Gamze Gökalp ${ }^{1}$, Yüksel Bıcılıŏglu' ${ }^{1}$, Fulya \\ Kamit-Can ${ }^{4}$, Fatih Durak ${ }^{4}$, Alkan Bal ${ }^{1}$, Neslihan Zengin ${ }^{4}$, Ayse Berna Anıl${ }^{2}$ \\ Departments of ${ }^{1}$ Pediatric Emergency, ${ }^{3}$ Emergency Biochemistry Laboratory and ${ }^{4}$ Pediatric Intensive Care Unit, Tepecik \\ Training and Research Hospital; ${ }^{2}$ Pediatric Intensive Care Unit, Katip Çelebi University Medical School, Izmir, Turkey. \\ E-mail: muratanil1969@gmail.com \\ Received: 18th November 2016, Revised 27th March 2017, Accepted: 16th April 2017
}

SUMMARY: Anıl M, Göç Z, Avcı R, Gökalp G, Bıcılığlu Y, Kamıt-Can F, Durak F, Bal A, Zengin N, Anıl AB. B-type natriuretic peptide is a useful biomarker predicting disease severity in children with isolated bronchiolitis in the emergency department. Turk J Pediatr 2017; 59: 561-569.

The aim of the study was to determine whether the B-type natriuretic peptide (BNP) plasma level predicted the severity of bronchiolitis without additional pathology in children admitted to an emergency department (ED). A total of 232 children (mean age: $7.7 \pm 1.2$ months [range: $1-23$ months]) presenting to ED with isolated bronchiolitis and 32 age- and gender-matched control subjects were included in the study. BNP levels differed significantly among the control $(8.5 \pm 1.1 \mathrm{pg} / \mathrm{ml})$ and mild $(27.7 \pm 2.6 \mathrm{pg} / \mathrm{ml})$, moderate $(51.4 \pm 0.5$ $\mathrm{pg} / \mathrm{ml})$, and severe $(106.8 \pm 4.8 \mathrm{pg} / \mathrm{ml})$ bronchiolitis groups $(\mathrm{p}<0.001)$. Clinical severity score $(\mathrm{p}<0.001$; OR: $2.524 ; 95 \% \mathrm{CI}$ : $1.826-3.487)$ and plasma BNP level ( $\mathrm{p}<0.001$; OR: 2.231; 95\% CI: 1.583-3.242) were independent risk factors for hospitalization. The length of hospital stay was significantly correlated with BNP level $(\mathrm{p}<0.001 ; \mathrm{r}$ : 0.698). In conclusion, the plasma BNP level may be a potent biomarker predicting disease severity in ED.

Key words: bronchiolitis, B-type natriuretic peptide, clinical severity, length of hospital stay, pediatric emergency department.

Bronchiolitis is a lower respiratory tract infection affecting principally the small airways. The disease is the most common cause of infant hospitalization during the winter months. In the USA, approximately 100,000 infants with bronchiolitis are admitted annually, and treatment costs reach $\$ 1.73$ billion. ${ }^{1,2}$ The latest American Academy of Pediatrics guidelines suggest that bronchiolitis should be diagnosed, and disease severity determined, by medical history-taking, physical examination, and pulse oximetry. Laboratory tests and radiological examinations are not routinely indicated for the diagnosis or evaluation of bronchiolitis. ${ }^{1}$ Assessment of clinical severity is important in daily pediatric emergency department (PED) practice and as an outcome measure in clinical trials. Vital signs, oxygen saturation, the effort of breathing, hydration status, age, and various clinical severity scores (CSSs) are used to predict the severity of disease. Many of these tools have not yet been formally validated. Furthermore, assessment of clinical severity may vary significantly among physicians. ${ }^{1,3,4}$

Brain natriuretic peptide (BNP) is a 32 -amino acid polypeptide secreted by the ventricles of the heart in response to excessive stretching of cardiomyocytes. The peptide exerts diuretic, natriuretic, and hypotensive effects. ${ }^{5}$ The principal clinical reason for measuring BNP level is that a normal level rules out heart failure in an emergency setting. ${ }^{6,7}$ Only a few studies have evaluated serum BNP levels in bronchiolitis patients. These studies focused on detection of heart failure in children with bronchiolitis and congenital heart disease. ${ }^{8,9}$ Plasma BNP levels are also increased in patients with pulmonary hypertension ${ }^{10}$, renal failure ${ }^{11}$, 
and sepsis. ${ }^{12}$ Some studies showed that hypoxia is a direct stimulus for BNP secretion that leads to pulmonary vasoconstriction, pulmonary hypertension and right ventricular overload 13-16. In the absence of heart failure, plasma BNP levels increase as disease severity advances in adult patients with pneumonia due to hypoxia. ${ }^{13,17,18}$ Because hypoxia is the most important factor that affects the disease severity of bronchiolitis ${ }^{1}$, we hypothesized that plasma BNP level induced by hypoxia may indicate the clinical severity of bronchiolitis in children without heart failure.

Very little is known about associations between the plasma BNP level and disease severity in children with isolated bronchiolitis. The purpose of the present prospective study was to determine if the plasma BNP level will be a predictor of the severity of isolated bronchiolitis in children admitted to a PED.

\section{Material and Methods}

All patients were children aged between 6 weeks and 24 months presenting to the PED of the Tepecik Teaching and Research Hospital with acute bronchiolitis. Recruitment commenced on January 1, 2015 and ended on March 31, 2015. Bronchiolitis was defined as a clinical syndrome developing in children $<2$ years of age that is characterized by initial upper respiratory tract symptoms (e.g., rhinorrhea), followed by lower respiratory infections with inflammation, causing wheezing and or crackles (rales) audible on auscultation ${ }^{1}$. Children with underlying chronic disease (including congenital or acquired heart pathology), any additional acute disease that could affect heart function (e.g., acute renal failure, myocarditis), or any recent history of surgery/major trauma/ burns, were excluded. When clinical findings (hepatomegaly, peripheral edema, a pathological murmur, an abnormal second heart sound, a gallop rhythm, a friction rub, central cyanosis, tachyarrhythmia, or signs of shock) were suggestive of heart failure in a patient with bronchiolitis, laboratory tests (BNP, troponin-I, etc.), telecardiography and echocardiography were performed, and a pediatric cardiology consultation was scheduled. Thus, those scheduled for the above mentioned further tests/consultation were excluded. All work was conducted in accordance with the dictates of the amended Declaration of Helsinki and was approved by our Institutional Review Board. Written informed consent was obtained from the parents or guardians of all patients. Enrollment occurred between approximately 08:00 and 17:00 on weekdays. After ED assessment, the investigator completed clinical severity scores (CSSs) based on respiratory rate (RR), wheezing, retraction, and general condition in a different location keeping the ED attending blinded and prior to ED interventions (such as suctioning, antipyretic medication, oxygen support, I.V. fluid, etc.). The minimum score was 0 , and the maximum 12 in CSS. All children were divided into three groups by their CSSs: $0-3$ points: mild; $4-8$ points: moderate; and 9-12 points: severe disease. ${ }^{19}$ The attending physicians treating the patient were blinded to the CCS determined by the investigator. All children meeting the inclusion criteria were invited to participate in the study. Body weight, axillary temperature, $\mathrm{RR}, \mathrm{SpO}_{2}$ in room air (determined via pulse oximetry), pulse rate (PR), medical history, and clinical findings were recorded. Vital signs and clinical findings were determined before interventions such as suctioning, antipyretic medication, oxygen support, and I.V. fluid. Serum BNP, troponin-I, glucose, sodium, potassium, calcium, urea, creatinine, aspartate aminotransferase, and alanine aminotransferase levels were measured, a complete blood count was performed, and venous blood gas levels were analyzed. The samples of the laboratory tests were taken after the basic interventions (nasal suctioning, oxygen support, etc.) were started. Other laboratory tests (e.g., of C-reactive protein and/or procalcitonin level), radiological tests (e.g., chest X-ray), and consultations were scheduled if the attending physician thought them necessary. At the end of clinical and laboratory assessments, all included patients had met the criteria described above, and thus had isolated bronchiolitis.

Children with severe bronchiolitis are routinely hospitalized and those with moderate disease managed up to six hours and usually admitted if not improved per our hospital guidelines. In the department of pediatrics, the patients are discharged according to predetermined criteria: respiratory rate $<60 /$ minute for age $<6$ months, $<55 /$ minute for age 6 to 11 months, and $<45$ breaths per minute for age 
$\geq 12$ months; parents know how to clear the infant's airway using bulb suctioning; patient is stable in room air; patient remains stable for at least 12 hours prior to discharge; patient has adequate oral intake; resources at home are adequate; parents are confident they can provide care at home; education of the family is complete; children maintain oxygen saturation $\geq 94 \%$ in room air. The investigators did not seek to influence treatment type or period, the decision to hospitalize, or the duration of hospital or PED stay. Thus, attending physicians who are not co-authors made all clinical decisions. The attending physicians in the PED and in the department of pediatrics were blinded to the BNP results.

The control group contained children 3-23 months of age without respiratory symptoms or underlying disease who received care in our ambulatory or emergency units. Only children scheduled for blood tests as part of their routine care were eligible to participate.

Blood samples were collected from peripheral veins (for BNP and Troponin-I, ADVIA Centaur ${ }^{\circledR}$ XP immunoassay system, Siemens [Erlangen]; for venous blood gas analysis, ABL 700 Series Radiometer [Copenhagen]). BNP levels were measured using a fully automated two-site sandwich immunoassay employing direct chemiluminescence technology. All analyses were performed in our ED laboratory.

All statistical analyses were performed with the aid of SPSS for Mac, version 20.0 (SPSS, Inc., Chicago). Categorical variables are expressed as numbers (n) with percentages (\%) and were compared using the chi-squared or Fisher's exact test, as appropriate. Continuous variables were expressed as means \pm standard deviations (range). The independent-samples t-test was used for between-group comparisons of continuous variables. Logistic regression was performed to identify independent risk factors for hospitalization. One-way analysis of variance (ANOVA) was employed to compare continuous variables among three independent groups. If the difference was significant, the comparisons were repeated using post hoc analysis (the Bonferroni test). Correlations were sought using Pearson's correlation test. A $\mathrm{p}$-value $<0.05$ was considered to reflect statistical significance.

\section{Results}

In all, 271 patients were assessed and 232 were included in the study (mean age: 7.7 \pm 1.2 months [range: 1-23 months]; male/ female: 167/65). On admission, 149 (64.2\%) were experiencing their first episodes of bronchiolitis, 45 (19.4\%) their second episodes, and $38(16.4 \%)$ were experiencing more than 2

Table I. Comparison of Patients with Mild, Moderate, and Severe Bronchiolitis and Controls, by Demographic Features, Body Weight, Birth Weight, Frequency of Premature Birth, Frequency of Firstepisode Bronchiolitis, and Frequency of Hospitalization.

\begin{tabular}{lccccc}
\hline Parameter & $\begin{array}{c}\text { Control } \\
\text { group } \\
\text { (n: 32) }\end{array}$ & $\begin{array}{c}\text { Mild } \\
\text { bronchiolitis } \\
\text { (n: 52) }\end{array}$ & $\begin{array}{c}\text { Moderate } \\
\text { bronchiolitis } \\
\text { (n: 145) }\end{array}$ & $\begin{array}{c}\text { Severe } \\
\text { bronchiolitis } \\
\text { (n: 35) }\end{array}$ & P \\
\hline Age (months) & $7.3 \pm 1.2$ & $7.0 \pm 2.2$ & $6.0 \pm 3.6$ & $6.0 \pm 3.2$ & 0.519 \\
& $(3-23)$ & $(3-22)$ & $(2-23)$ & $(2-23)$ & \\
$\begin{array}{l}\text { Gender, n(\%) } \\
\quad \text { Male }\end{array}$ & $19(59.4)$ & $38(26.9)$ & $105(27.6)$ & $24(31.4)$ & 0.884 \\
$\quad$ Female & $13(40.6)$ & $14(73.1)$ & $40(72.4)$ & $11(68.6)$ & \\
Body weight* (kg) & $8.2 \pm 0.7$ & $8.0 \pm 1.1$ & $7.5 \pm 2.1$ & $7.4 \pm 2.5$ & 0.071 \\
& $(5-13)$ & $(4.6-12)$ & $(4-12.5)$ & $(4.2-14)$ & \\
Birth weight* (g) & $3040.2 \pm 234.0$ & $3300.0 \pm 700.2$ & $3070.5 \pm 345.4$ & $3000.6 \pm 700$ & 0.092 \\
& $(2,000-3,650)$ & $(1,950-3,600)$ & $(2,040-4,000)$ & $(1,800-4,200)$ & \\
Prematurity (Yes), n(\%) & $4(12.5)$ & $7(13.5)$ & $23(15.9)$ & $7(20)$ & 0.816 \\
$\begin{array}{l}\text { First bronchiolitis episode } \\
\text { (Yes), n(\%) }\end{array}$ & - & $32(61.5)$ & $98(67.6)$ & $19(54.3)$ & 0.304 \\
$\begin{array}{l}\text { Prior hospitalization for } \\
\text { bronchiolitis (Yes), n(\%) }\end{array}$ & - & $5(9.6)$ & $21(14.5)$ & $5(14.3)$ & 0.666 \\
\hline
\end{tabular}

*: Data is presented as mean \pm SD (minimum-maximum). 
episodes. Of all patients, 37 (15.9\%) had been born prematurely. Thirty-three patients $(14.2 \%)$ had been hospitalized at least once in the past for bronchiolitis, but none had been admitted to the pediatric intensive care unit (PICU). The patients were divided into three groups based on their CSS values on admission to the PED: mild (52 patients, $22.4 \%$ ), moderate $(145,62.5 \%)$, and severe $(35,15 \%)$ disease. A control group $(n=32)$ was also included in the analysis. Troponin-I levels were normal in all children. The patients and controls did not differ in age, gender, body weight, birth weight, or frequencies of premature birth, first-episode bronchiolitis, or hospitalization rate (all p-values >0.05) (Table I).

We compared patients with mild, moderate, and severe bronchiolitis and controls in terms of vital signs, serum BNP level and peripheral venous gas analysis results. We found significant differences in pulse rate, $\mathrm{RR}, \mathrm{SpO}_{2}$, venous $\mathrm{pH}$, venous $\mathrm{pCO}_{2}$, and plasma $\mathrm{BNP}$ level (all p-values <0.05) (Table II). Serum BNP levels were measured as $60.8 \pm 5.4 \mathrm{pg} / \mathrm{ml}$ in patients with a pulse rate $\leq 160 /$ minute and as $77.7 \pm 11.7 \mathrm{pg} / \mathrm{ml}$ in patients with a pulse rate $>160 /$ minute. This difference was not statistically significant (p: $0.144 ; 95 \% \mathrm{CI}$ : $-44.8-6.6)$.

A total of 173 patients $(74.5 \%)$ were hospitalized. No patient died. Hospitalized and discharged patients were compared in terms of age, gender, body weight, birth weight, frequencies of premature birth, first-episode bronchiolitis, and hospitalization, vital signs, peripheral venous blood gas parameters; and plasma BNP level. Hospitalized patients were younger and had higher pulse rate and $\mathrm{RR}$, lower $\mathrm{SpO}_{2}$, higher CSS, higher venous $\mathrm{pCO}_{2}$, and higher plasma BNP levels (all p-values

Table II. Comparison of Patients with Mild, Moderate, and Severe Bronchiolitis and Controls, by Vital Signs, Venous Blood Gas Parameters, and Plasma BNP Level.

\begin{tabular}{|c|c|c|c|c|c|}
\hline Parameters & $\begin{array}{l}\text { Control } \\
\text { group } \\
(\mathrm{N}: 32)\end{array}$ & $\begin{array}{l}\text { Mild } \\
\text { bronchiolitis } \\
(\mathrm{N}: 52)\end{array}$ & $\begin{array}{l}\text { Moderate } \\
\text { bronchiolitis } \\
\text { (N: 145) }\end{array}$ & $\begin{array}{l}\text { Severe } \\
\text { bronchiolitis } \\
(\mathrm{N}: 35)\end{array}$ & $\mathrm{P}$ \\
\hline Body temperature $\left({ }^{\circ} \mathrm{C}\right)$ & $\begin{array}{c}37.1 \pm \\
0.2 \\
(36.4- \\
37.9)\end{array}$ & $\begin{array}{l}37.2 \pm 0.5 \\
(36.5-38.9)\end{array}$ & $\begin{array}{l}37.4 \pm 0.7 \\
(36.4-39.5)\end{array}$ & $\begin{array}{c}37.4 . \pm 0.7 \\
(36-39)\end{array}$ & 0.129 \\
\hline Pulse rate $(\mathrm{n} / \mathrm{min})$ & $\begin{array}{c}128.4 \pm \\
0.9 \\
(96-161)\end{array}$ & $\begin{array}{c}138.4 \pm 20.9 \\
(102-185)\end{array}$ & $\begin{array}{c}147.3 \pm 18.6 \\
(110-190)\end{array}$ & $\begin{array}{c}156.5 \pm \\
19.7 \\
(133-196)\end{array}$ & $<0.001^{*}$ \\
\hline Respiratory rate (n/min.) & $\begin{array}{c}31.2 \pm \\
1.9 \\
(26-48)\end{array}$ & $\begin{array}{c}41.2 \pm 1.9 \\
(26-62)\end{array}$ & $\begin{array}{c}53.1 \pm 2.4 \\
(30-80)\end{array}$ & $\begin{array}{c}60.2 \pm 1.3 \\
(33-85)\end{array}$ & $<0.001^{*}$ \\
\hline Oxygen saturation (\%) & $\begin{array}{c}97.0 \pm \\
0.1 \\
(96-99)\end{array}$ & $\begin{array}{c}96.0 \pm 2.1 \\
(90-99)\end{array}$ & $\begin{array}{c}94.2 \pm 3.3 \\
(87-99)\end{array}$ & $\begin{array}{c}93.1 \pm 3.0 \\
(85-99)\end{array}$ & $<0.001^{*}$ \\
\hline $\mathrm{pH}$ & - & $\begin{array}{c}7.34 \pm 0.00 \\
(7.30-7.40)\end{array}$ & $\begin{array}{c}7.35 \pm 0.08 \\
(7.30-7.40)\end{array}$ & $\begin{array}{c}7.29 \pm 0.09 \\
(7.23-7.35)\end{array}$ & $0.023^{* *}$ \\
\hline $\mathrm{pCO}_{2}(\mathrm{mmHg})$ & - & $\begin{array}{c}34.1 \pm 4.3 \\
(28-43)\end{array}$ & $\begin{array}{c}39.6 \pm 5.6 \\
(30-63)\end{array}$ & $\begin{array}{c}46.5 \pm 3.1 \\
(32-75)\end{array}$ & $0.004^{* *}$ \\
\hline $\mathrm{HCO}_{3}(\mathrm{mEq} / \mathrm{L})$ & - & $\begin{array}{l}20.6 \pm 2.1 \\
(15.0-22.0)\end{array}$ & $\begin{array}{c}20.4 \pm 2.7 \\
(16.5-28)\end{array}$ & $\begin{array}{c}19.8 \pm 1.7 \\
(16.0-25)\end{array}$ & 0.176 \\
\hline Base excess $(\mathrm{mmol} / \mathrm{L})$ & - & $\begin{array}{c}-7.3 \pm 0.3 \\
(-8.4)-(-4.9)\end{array}$ & $\begin{array}{c}-5.2 \pm 0.1 \\
(-7.7)-(-3.1)\end{array}$ & $\begin{array}{c}-6.2 \pm 0.2 \\
(-8.0)-(-4.1)\end{array}$ & 0.856 \\
\hline Lactate $(\mathrm{mmol} / \mathrm{L})$ & - & $\begin{array}{c}2.2 \pm 0.1 \\
(0.9-3.1)\end{array}$ & $\begin{array}{c}1.7 \pm 0.9 \\
(0.2-3.0)\end{array}$ & $\begin{array}{c}2.0 \pm 0.7 \\
(0.7-3.2)\end{array}$ & 0.301 \\
\hline BNP (pg/ml) & $\begin{array}{l}8.5 \pm 1.1 \\
(2.2-14.0)\end{array}$ & $\begin{array}{c}27.7 \pm 2.6 \\
(8.2-65)\end{array}$ & $\begin{array}{l}51.40 \pm 0.5 \\
(25.3-167.2)\end{array}$ & $\begin{array}{c}106.8 \pm 4.8 \\
(36-277.9)\end{array}$ & $<0.001^{*}$ \\
\hline
\end{tabular}

Data is presented as mean \pm SD(range). BNP: B-type natriuretic peptide; *: All groups differed significantly from one another. ${ }^{* *}$ : The severe bronchiolitis group differed significantly from all other groups. 
Table III. Comparison of Hospitalized Patients and Those Discharged From The Emergency Department by Age, Gender, Body Weight, Birth Weight, Frequency of Premature Birth, Frequency of First-Episode Bronchiolitis, Hospitalization Rate, Vital Signs, Peripheral Venous Blood Gas Parameters, and Plasma BNP Level.

\begin{tabular}{|c|c|c|c|c|c|}
\hline \multirow[t]{2}{*}{ Parameters } & \multirow{2}{*}{$\begin{array}{l}\text { Discharged } \\
\text { patients } \\
(\mathrm{N}: 59)\end{array}$} & \multirow{2}{*}{$\begin{array}{l}\text { Hospitalized } \\
\text { patients } \\
(\mathrm{N}: 173)\end{array}$} & \multirow[t]{2}{*}{$\mathrm{P}$} & \multicolumn{2}{|c|}{ Logistic regression analysis } \\
\hline & & & & $\mathrm{P}$ & $\begin{array}{c}\text { Odss Ratio } \\
\text { (95\% Confidence } \\
\text { Interval) }\end{array}$ \\
\hline Age (months) & $\begin{array}{l}9.7 \pm 2.1 \\
\quad(1-23)\end{array}$ & $\begin{array}{c}7.0 \pm 0.4 \\
(1-23)\end{array}$ & 0.010 & 0.432 & - \\
\hline Gender & & & & - & - \\
\hline Male & 48 (81.4) & $119(68.8)$ & 0.063 & & \\
\hline Female & 11 (18.6) & $54 \quad(31.2)$ & & & \\
\hline Body weight $(\mathrm{kg})$ & $\begin{array}{c}8.6 \pm 2.3 \\
(4.5-15)\end{array}$ & $\begin{array}{l}7.4 \pm 2.5 \\
(3.3-16)\end{array}$ & 0.001 & 0.079 & - \\
\hline Birth weight (g) & $\begin{array}{c}3165.0 \pm 602.0 \\
(1,950-4,000)\end{array}$ & $\begin{array}{c}3013.4 \pm 659.1 \\
(1,800-4,200)\end{array}$ & 0.154 & - & - \\
\hline Prematurity (Yes) & $\begin{array}{c}10 \\
(16.9)\end{array}$ & $\begin{array}{c}27 \\
(15.6)\end{array}$ & 0.808 & - & - \\
\hline $\begin{array}{l}\text { First bronchiolitis } \\
\text { episode (Yes) }\end{array}$ & $\begin{array}{c}32 \\
(54.2)\end{array}$ & $\begin{array}{c}117 \\
(67.6)\end{array}$ & 0.064 & - & - \\
\hline $\begin{array}{l}\text { A hospitalization } \\
\text { history for } \\
\text { bronchiolitis prior } \\
\text { to current admission } \\
\text { (Yes) }\end{array}$ & $\begin{array}{c}8 \\
(14.0)\end{array}$ & $\begin{array}{c}23 \\
(13.1)\end{array}$ & 0.864 & - & - \\
\hline $\begin{array}{l}\text { Body temperature } \\
\left({ }^{\circ} \mathrm{C}\right)\end{array}$ & $\begin{array}{l}37.2 \pm 0.3 \\
(36.6-38.9)\end{array}$ & $\begin{array}{l}37.4 \pm 0.2 \\
(36.6-38.9)\end{array}$ & 0.059 & - & - \\
\hline Pulse rate $(\mathrm{n} / \mathrm{min})$ & $\begin{array}{c}138.8 \pm 19.1 \\
(102-179)\end{array}$ & $\begin{array}{l}149.4 \pm 19.5 \\
(110-196)\end{array}$ & $<0.001$ & 0.089 & - \\
\hline $\begin{array}{l}\text { Respiratory rate (n/ } \\
\text { min.) }\end{array}$ & $\begin{array}{l}43.3 \pm 10.1 \\
(26-80)\end{array}$ & $\begin{array}{l}54.5 \pm 10.3 \\
\quad(33-85)\end{array}$ & $<0.001$ & 0.056 & - \\
\hline $\begin{array}{l}\text { Oxygen saturation } \\
(\%)\end{array}$ & $\begin{array}{l}95.4 \pm 2.3 \\
(90-99)\end{array}$ & $\begin{array}{l}93.1 \pm 3.3 \\
(85-99)\end{array}$ & 0.005 & 0,154 & - \\
\hline $\begin{array}{l}\text { Clinical severity } \\
\text { score }\end{array}$ & $\begin{array}{c}5 \\
(4-7)\end{array}$ & $\begin{array}{c}7 \\
(5-8)\end{array}$ & $<0.001$ & $<0.001$ & $\begin{array}{c}2.524 \\
(1.826-3.487)\end{array}$ \\
\hline Venous $\mathrm{pH}$ & $\begin{array}{c}7.33 \pm 0.02 \\
(7.27-7.40)\end{array}$ & $\begin{array}{c}7.29 \pm 0.08 \\
(7.10-7.43)\end{array}$ & 0.245 & - & - \\
\hline $\begin{array}{l}\text { Venous } \mathrm{pCO}_{2} \\
(\mathrm{~mm} \mathrm{Hg})\end{array}$ & $\begin{array}{l}34.9 \pm 4.3 \\
(25.6-43.1)\end{array}$ & $\begin{array}{l}39.1 \pm 1.6 \\
(24.1-59.0)\end{array}$ & 0.016 & 0,376 & - \\
\hline $\begin{array}{l}\text { Base excess } \\
(\mathrm{mmol} / \mathrm{L})\end{array}$ & $\begin{array}{c}(-5.6) \quad \pm 0.6 \\
{[(-10.6)-(-1.7)]}\end{array}$ & $\begin{array}{c}(-4.6) \quad \pm 0.2 \\
{[(-12.8)-(-2.9)]}\end{array}$ & 0.195 & - & - \\
\hline Bicarbonate $(\mathrm{mEq} / \mathrm{L})$ & $\begin{array}{c}19.8 \pm 1.9 \\
(16.6-23)\end{array}$ & $\begin{array}{c}20.8 \pm 3.4 \\
(19.8-28)\end{array}$ & 0.240 & - & - \\
\hline Lactate $(\mathrm{mmol} / \mathrm{L})$ & $\begin{array}{l}1.9 \pm 0.1 \\
(0.8-4.1)\end{array}$ & $\begin{array}{l}1.8 \pm 0.8 \\
(0.1-3.7)\end{array}$ & 0.698 & - & - \\
\hline $\mathrm{BNP}(\mathrm{pg} / \mathrm{ml})$ & $\begin{array}{c}32.6 \pm 6.7 \\
(0-98.1)\end{array}$ & $\begin{array}{c}57.1 \pm 5 \\
(11.8-277.9)\end{array}$ & 0.003 & $<0.001$ & $\begin{array}{c}2.231 \\
(1.583-3.242)\end{array}$ \\
\hline
\end{tabular}

BNP: B-type natriuretic peptide. Data is presented as mean $\pm \mathrm{SD}$ (range) or $\mathrm{n}(\%)$. 
$<0.05)$. Upon logistic regression analysis, the CSS ( $p<0.001$; OR: 2.524; 95\% CI: $1.826-$ 3.487) and the plasma BNP level $(\mathrm{p}<0.001$; OR: 2.231; 95\% CI: 1.583-3.242) significantly predicted hospitalization (Table III).

Correlations of the length of hospital stay (LOS) with patient age, body weight, birth weight, vital signs at admission, CSS, $\mathrm{SpO}_{2}$ at admission, venous blood gas parameters, and plasma BNP level were assessed. LOS was significantly correlated with patient age (negative correlation), body weight (negative correlation), RR (positive correlation), CSS (positive correlation), $\mathrm{SpO}_{2}$ (negative correlation), and plasma BNP level (positive correlation) (all p-values $<0.05$ ). The highest correlation was found between the LOS and plasma BNP level at admission ( $p<0.001$; $r$ $=0.698)$ (Table IV).

Three children $(1.2 \%)(4,6$, and 12 months of age; two males and one female; plasma BNP levels 277.5, 163.2, and $150 \mathrm{pg} / \mathrm{ml}$ ) were admitted to the PICU. Only one patient (a male aged 12 months, BNP $=150.3 \mathrm{pg} /$ $\mathrm{ml}$ ) was intubated; mechanical ventilation was maintained for 5 days.

\section{Discussion}

We prospectively studied 232 children with bronchiolitis presenting to a PED, evaluating whether the plasma BNP level could predict disease severity. The plasma BNP level was positively correlated with disease severity in children without heart disease or any chronic pathology. At the time of PED admission, we found that the CSS and the plasma BNP level were the most effective predictors for hospitalization in children with bronchiolitis. Furthermore, the plasma BNP level at admission to the PED was positively correlated with LOS in hospitalized patients.

Natriuretic peptide levels can be used to rule out cardiac disease in infants and young children ${ }^{20-22}$. Cardiovascular complications are rare in infants with bronchiolitis. Most such complications develop in infants with both bronchiolitis and congenital heart disease or other congenital anomalies. ${ }^{23} \mathrm{~A}$ few studies have explored whether natriuretic peptide levels can be used to detect heart failure in children under respiratory distress. ${ }^{8,9,21,22}$ Koulouri et al. ${ }^{22}$ found that the plasma BNP level (693 $\mathrm{pg} / \mathrm{ml}$ ) in the 23 children with congestive heart failure was significantly higher than in the 26 children with lung disease (pneumonia, bronchiolitis, asthma; median BNP: $45.2 \mathrm{pg} /$ $\mathrm{ml})$. Cohen et al. ${ }^{21}$ reported that median plasma amino terminal pro-brain-type natriuretic peptide level of 17 infants with congestive heart failure were significantly different from the 18 infants with lung disease and the control group consisted of 13 infants. Samuel et al. ${ }^{8}$ focused on the 18 cases with bronchiolitis and congenital heart disease in their study. Among the study group, 7 infants had heart failure, and their BNP levels were significantly higher than the others (783 vs. $59 \mathrm{pg} / \mathrm{ml}$ ). But only

Table IV. Correlations of LOS with Patient Age, Body Weight, Birth Weight, Vital Signs, $\mathrm{CSS}, \mathrm{SpO}_{2}$, Venous Blood Gas Parameters, and Plasma BNP Level.

\begin{tabular}{lcc}
\hline Parameter & $\mathrm{P}$ & $\mathrm{r}$ \\
\hline Age $($ months) & 0.046 & -0.131 \\
Weight $(\mathrm{g})$ & 0.006 & -0.185 \\
Birth weight $(\mathrm{g})$ & 0.539 & -0.041 \\
Pulse rate $(\mathrm{n} / \mathrm{min})$ & 0.068 & 0.120 \\
Respiratory rate $(\mathrm{n} / \mathrm{min})$ & $<0.001$ & 0.331 \\
Oxygen saturation (\%) & 0.002 & -0.205 \\
$\mathrm{pH}$ & 0.069 & -0.188 \\
$\mathrm{pCO}(\mathrm{mm} \mathrm{Hg})$ & 0.031 & 0.215 \\
Lactate $(\mathrm{mmol} / \mathrm{L})$ & 0.401 & 0.095 \\
Clinical severity score & $<0.001$ & 0.462 \\
BNP (pg/ml) & $<0.001$ & 0.698 \\
\hline
\end{tabular}

BNP: B-type natriuretic peptide. 
3 infants received pharmacological treatment for heart failure. According to their results, a BNP level of $95 \mathrm{pg} / \mathrm{ml}$ was optimal cutoff level for determine the heart failure. They stated that BNP test could be useful to determine the presence of heart failure in infants with congenital heart disease who present to the emergency department with bronchiolitis. Sahingozlu et al. ${ }^{9}$ aimed to investigate that whether plasma BNP test could differentiate between heart failure and lung disease among infants with acute bronchiolitis. BNP level was measured as $118.9 \mathrm{pg} / \mathrm{ml}$ in 49 infants with isolated bronchiolitis, and it was $841.2 \mathrm{pg} / \mathrm{ml}$ in 19 infants with congenital heart disease. 18 infants received diuretic treatment. The BNP level of control group was $11.6 \mathrm{pg} / \mathrm{ml}$. They also found that BNP level was not different between the infants with severe bronchiolitis (BNP: $243.6 \mathrm{pg} / \mathrm{ml}$ ) and the infants with moderatemild bronchiolitis (BNP: 258.4). In these limited number of clinical trials, the primary purpose was to determine heart failure in children with bronchiolitis. None of them aimed to evaluate the role of natriuretic peptides in predicting severity of isolated bronchiolitis. Unlike other studies, we explored whether the BNP level predicted disease severity in children with isolated bronchiolitis. The BNP levels in children of our study ranged from 8.2 to 277.5 $\mathrm{pg} / \mathrm{ml}$. Our study group consisted of children without chronic disease and thus without heart pathology. Therefore, the BNP levels of the children studied were lower than those of children in previous studies (mild: $27.7 \mathrm{pg}$ / $\mathrm{ml}$, moderate: $51.4 \mathrm{pg} / \mathrm{ml}$, and severe disease: $106.8 \mathrm{pg} / \mathrm{ml}$ ), but significantly higher than that of the control group (mean: $8.5 \mathrm{pg} / \mathrm{ml}$ ). Three children with severe disease were admitted to our PICU, and one required mechanical ventilation. However, none had clinical features of heart failure, and none required cardiac support. Thus, bronchiolitis alone increased the plasma BNP level, which rose with increased clinical severity of bronchiolitis.

Secretion of natriuretic peptide is caused by heart failure and tissue hypoxia, and it may trigger pulmonary vasoconstriction and hypertension and right ventricular overload. ${ }^{14-16}$ Furthermore, an inflammatory response can increase BNP levels. ${ }^{24}$ Only a few studies have focused on associations between BNP levels and the severity of community-acquired pneumonia in patients treated in adult EDs or outpatient settings. BNP levels were correlated with pneumonia severity, and the prognostic accuracy of the BNP level was close to that of the Pneumonia Severity Score. 13,17,18 The BNP level was also correlated with the C-reactive protein level ${ }^{13,25}$ and could be used to predict death $^{17,18}$ and treatment failure ${ }^{18}$ in ED patients with community-acquired pneumonia. In our study, according to the comparison of hospitalized patients and those discharged from the emergency department, the patient age, body weight, and oxygen saturation were lower, and the rate of male gender, pulse rate, respiratory rate, CSS, venous $\mathrm{pCO}_{2}$ level, and plasma BNP level were higher in hospitalized children with bronchiolitis. Nevertheless, the multivariate analysis showed that the CSS and plasma BNP level were significant predictors of hospitalization in children with bronchiolitis. Furthermore, the plasma BNP level at admission was significantly correlated with LOS in hospitalized children with bronchiolitis. The correlation of BNP level with LOS was higher than those with patient age, body weight, $\mathrm{RR}$, oxygen saturation, $\mathrm{pCO}_{2}$, and CSS. Thus, the BNP level usefully predicts morbidity in children with isolated bronchiolitis, as well as in adult patients with pneumonia.

The latest bronchiolitis guidelines suggest that clinical severity should be assessed by evaluating RR, retraction status, and oxygen saturation ${ }^{1}$. However, this recommendation has been criticized. ${ }^{26,27}$ Additionally, interobserver agreement is an important issue when calculating CSS values for bronchiolitis patients. ${ }^{28}$ We found that the BNP level at the time of admission to the ED yielded objective and accurate information on bronchiolitis severity and morbidity in children.

In our study, the hospitalization rate was high. We believe this result was related to the location of our hospital. It is in downtown and is closed to people of low socio-economic level and refugees. Based on past experience, some risk factors, such as passive smoking, crowded household, greater number of siblings, low rate of feeding with breast milk can contribute to more severe disease in our patient population.

There are some limitations in our study. Firstly, the interventions and treatments were not addressed in the study. Secondly, we evaluated 
the patients only seen during the day shift, so we missed the patients admitted in the evening or night. Thirdly, we did not explore whether the BNP level predicted re-admission of children with bronchiolitis.

In conclusion, the plasma BNP level at admission reflects the severity of bronchiolitis. In pediatric emergency setting, the plasma BNP level and CSS are strong predictors of hospitalization. The BNP level strongly correlated with LOS in children without chronic disease who presented to a PED with bronchiolitis. The BNP measurement afforded accurate and objective information on disease severity in children with isolated bronchiolitis.

\section{REFERENCES}

1. Ralston SL, Lieberthal AS, Meissner HC, et al. The diagnosis, management, and prevention of bronchiolitis. Pediatrics 2014; 134: 1474-1502.

2 Hasegawa K, Tsugawa Y, Brown DF, Mansbach JM, Camargo CA Jr. Trends in bronchiolitis hospitalizations in the United States, 2000-2009. Pediatrics 2013; 132: 28-36.

3. Bekhof J, Reimink R, Brand PL. Systematic review: Insufficient validation of clinical scores for the assessment of acute dyspnoea in wheezing children. Paediatr Respir Rev 2014; 15: 98-112.

4. Destino L, Weisgerber MC, Soung P, et al. Validity of respiratory scores in bronchiolitis. Hosp Pediatr 2012; 2: 202-209.

5. Brunner-La Rocca HP, Kaye DM, Woods RL, et al. Effects of intravenous brain natriuretic peptide on regional sympathetic activity in patients with chronic heart failure as compared with healthy control subjects. J Am Coll Cardiol 2001; 37: 1221-1227.

6. Hill SA, Booth RA, Santaguida PL, et al. Use of BNP and NT-proBNP for the diagnosis of heart failure in the emergency department: A systematic review of the evidence. Heart Fail Rev 2014; 19: 421-438.

7. Maisel AS, Krishnaswamy P, Nowak RM, et al. Rapid measurement of B-type natriuretic peptide in the emergency diagnosis of heart failure. $\mathrm{N}$ Engl J Med 2002; 347: 161-167.

8. Samuel N, Hershkovitz T, Brik R, et al. Diagnosing heart failure in children with congenital heart disease and respiratory syncytial virus bronchiolitis. Am J Emerg Med 2014; 32: 1510-1512.

9. Sahingozlu T, Karadas U, Eliacik K, et al. Brain natriuretic peptide: the reason of respiratory distress is heart disease or lung disease? Am J Emerg Med 2015; 33: 697-700.

10. Leuchte HH, Holzapfel M, Baumgartner RA, et al. Clinical significance of brain natriuretic peptide in primary pulmonary hypertension. J Am Coll Cardiol 2004; 43: 764-770.
11. McCullough PA, Duc P, Omland T, et al. B-type natriuretic peptide and renal function in the diagnosis of heart failure: An analysis from the Breathing Not Properly Multinational Study. Am J Kidney Dis 2003; 41: 571-579.

12. Rudiger A, Gasser S, Fischler M, et al. Comparable increase of B-type natriuretic peptide and aminoterminal pro-B-type natriuretic peptide levels in patients with severe sepsis, septic shock, and acute heart failure. Crit Care Med 2006; 34: 2140-2144.

13. Li J, Ye H, Zhao L. B-type natriuretic peptide in predicting the severity of community-acquired pneumonia. World J Emerg Med 2015; 6: 131-136.

14. Ando T, Ogawa K, Yamaki K, et al. Plasma concentrations of atrial, brain, and C-type natriuretic peptides and endothelin-1 in patients with chronic respiratory diseases. Chest 1996; 110: 462-468.

15. Hopkins WE, Chen Z, Fukagawa NK, et al. Increased atrial and brain natriuretic peptides in adults with cyanotic congenital heart disease: Enhanced understanding of the relationship between hypoxia and natriuretic peptide secretion. Circulation 2004; 109: 2872-2877.

16. Yap LB, Mukerjee D, Timms PM, et al. Natriuretic peptides, respiratory disease, and the right heart. Chest 2004; 126: 1330-1336.

17. Nowak A, Breidthardt T, Christ-Crain M, et al. Direct comparison of three natriuretic peptides for prediction of short- and long-term mortality in patients with community-acquired pneumonia. Chest 2012; 141 : 974-982.

18. Christ-Crain M, Breidthardt T, Stolz D, et al. Use of B-type natriuretic peptide in the risk stratification of community-acquired pneumonia. J Intern Med 2008; 264: 166-176.

19. Wang EEL, Milner RA, Navas L, et al. Observer agreement for respiratory signs and oximetry in infants hospitalized with lower respiratory infections. Am Rev Respir Dis 1992; 145: 106-109.

20. Hammerer-Lercher A, Geiger R, Mair J, et al. Utility of $\mathrm{N}$-terminal pro-B-type natriuretic peptide to differentiate cardiac diseases from noncardiac diseases in young pediatric patients. Clin Chem 2006; 52: 1415-1419.

21. Cohen S, Springer C, Avital A, et al. Amino-terminal pro-brain-type natriuretic peptide: heart or lung disease in pediatric respiratory distress? Pediatrics 2005; 115: 1347-1350.

22. Koulouri S, Acherman RJ, Wong PC, et al. Utility of B-type natriuretic peptide in differentiating congestive heart failure from lung disease in pediatric patients with respiratory distress. Pediatr Cardiol 2004; 25: 341-346.

23. Willson DF, Landrigan CP, Horn SD, et al. Complications in infants hospitalized for bronchiolitis or respiratory syncytial virus pneumonia. J Pediatr 2003; 143: 142149.

24. Shor R, Rozenman Y, Bolshinsky A, et al. BNP in septic patients without systolic myocardial dysfunction. Eur J Intern Med 2006; 17: 536-540. 
25. Yetkin O, Hacievliyagil SS, Gunen H. Assessment of B-type natriuretic peptide in patients with pneumonia. Int J Clin Pract 2008; 62: 488-491.

26. Corneli HM, Zorc JJ, Holubkov R, et al; Bronchiolitis Study Group for the Pediatric Emergency Care Applied Research Network. Bronchiolitis: clinical characteristics associated with hospitalization and length of stay. Pediatr Emerg Care 2012; 28: 99-103.
27. Schuh S, Freedman S, Coates A, et al. Effect of oximetry on hospitalization in bronchiolitis: a randomized clinical trial. JAMA 2014; 312: 712-718.

28. Liu LL, Gallaher MM, Davis RL, et al. Use of a respiratory clinical score among different providers. Pediatr Pulmonol 2004; 37: 243-248. 